\author{
Piotr KOLASA ${ }^{1}$ \\ Mirosław JANOWSKI ${ }^{2}$
}

\title{
VIRTUAL ENERGY STORING SYSTEM (VESS) AND ITS BEING IN THE SMART GRID SYSTEM
}

\begin{abstract}
The study shows a virtual way to store energy in a grid treating the grid itself and all connected energy consumers as one energy storing system. The described system is supplied with energy being produced in a traditional way and from alternative energy sources. Additionally, it consumes the energy through a large group of dispersed customers. The theory is based on the changes of the time zones, which determines the different consumption of energy at different times and locations. In a micro scale, the system is not complementary and requires input at peak power times as well as additional storage. However, in the following estimation it is not necessary to construct large energy storage systems but eventually a combination of smaller storage units, if needed. This is a common phenomenon, to use an energy system as a kind of buffer, but if we consider it is a system to store energy, new ideas about its development come to mind. In the article several methods of calculation of energy flow are shown. There are two possibilities described. The first one occurs when the customer produces and stores the energy in the grid to use it later in the same location. The second one consists in producing energy in one location and using it in another one. Is such an approximation the grid is not only the place to store energy, but also to transfer to another place.
\end{abstract}

Keywords: Energy storage, Grid, Virtual, Smart grid, Smart metering, VESS, Grid Storage Fees, GSF.

\section{INTRODUCTION}

The analysis of a number of papers and technical documents prove there is no perfect solution for energy storing among commercial and industrial facilities. Energy storing is a topic that is very complicated from the technical point of view. The whole cost plus the environmental impact plays an important role and makes the scheme generally unprofitable. From the commercial point of view the energy storing needs to be developed and a proper transmission grid built.

The question is, if there is a possibility to store energy in the distribution system and if the grid can play a role in such a wide storage system.

\footnotetext{
${ }^{1}$ Piotr Kolasa, Laboratory of Innovation in Bio and Renewable Energy, LIBRE Foundation, Poland, 44-100 Gliwice, ul. Kościuszki 35; e-mail: pkolasa@librefoundation.org; tel.: +48 691929508

2 Mirosław Janowski, AGH University of Science and Technology, Poland 30-059 Kraków, Mickiewicza 30.
} 


\section{SIMULATION MODEL}

The study has been done after running dozens of hybrid complex simulations with the use of Polysun Simulation Software. The more complex the system is, the more energy efficiency results appear in the report. For example, the simple photovoltaic system is a good solution to produce energy from a free available source. Although some problems appear at a time when the sky is cloudy or when there is no solar energy during the night. In such situations we need an auxiliary energy generator or other equipment, which helps us to cover the energy demand. Another situation is when the installation is oversized, in some periods we can get more energy than we can use. So then we need to store it or transfer it to another consumer.

We can build an energy efficient system, if we produce at least the same amount of energy as we use. But in a situation when we have excess energy we can feed it to the Grid, building an autonomic system is financially unreasonable. The Grid can be used to transfer energy to another point. If we produce energy $\mathrm{Q}$ in the above mentioned PV installation, we can store it $\left(\mathrm{Q}_{2}\right)$, use immediately $\left(\mathrm{Q}_{3}\right)$, and transfer the rest to the grid $\left(\mathrm{Q}_{1}\right)$, Figure 1 . The whole energy produced can be described as follows:

$$
Q=\sum Q_{i}
$$

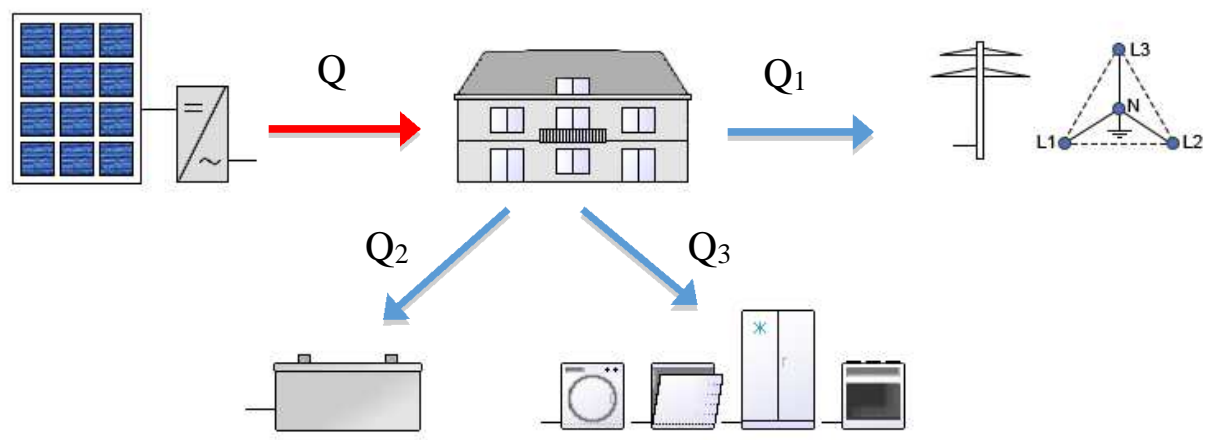

Figure 1. Distribution of energy produced by the PV system, where Q is the whole energy produced, $\mathrm{Q}_{1}$ is the energy transferred to the Grid, $\mathrm{Q}_{3}$ the energy used immediately and $\mathrm{Q}_{2}$ is the stored energy, (Ref I)

When there is no energy production in the PV system, all needed energy must be transferred from the Grid. That means that

$$
Q_{1}=Q_{3}\left(+Q_{2},-Q_{2}^{\prime}\right)
$$

where $\left(+Q_{2},-Q^{\prime}{ }_{2}\right)$ plus or minus signs depends on the way the battery works (charging $Q_{2}$, discharging $Q_{2}^{\prime}=Q_{2} \eta$, where $\eta<1$ ). Figure 2 . We can treat the Grid as a place to store energy, when we produce more than we use. When we need more energy, we can get energy from the Grid. Grid losses correspond to the energy losses due to the self-discharge of batteries. Therefore, in both cases we need to cover the costs of energy losses, by using an 
opportunity to use energy exchange with the Grid we have no investment costs. The costs of energy storing equipment are significant and in most of the cases make the whole project unprofitable.

A method of energy management according to the suggested idea is, that the energy is stored in a transmission Grid at a predetermined time. It is introduced into the Grid through the connection system and the volume of stored energy is determined by means of counters, eventually a two way counter. With the use of meters the amount of energy used on both sides: from client to the Grid and from the Grid to the client is separately measured. The energy balance of stored energy in the transmission Grid is settled on the basis of the difference between both measurements in a given period of time.

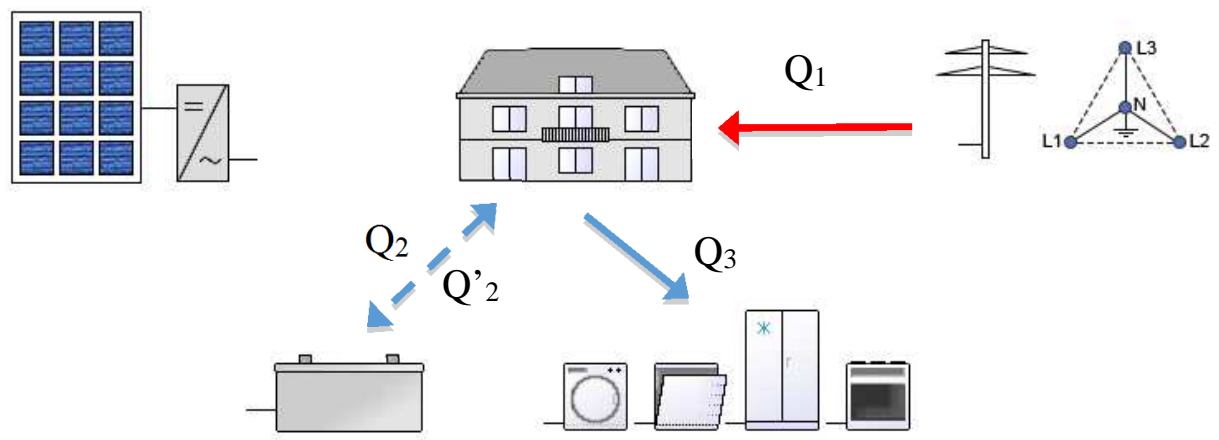

Figure 2. Getting of the stored in grid energy, (Ref I)

The way of power management should run automatically to eliminate the possibility of human error.

The method of managing energy is carried out by means of software and hardware, or hardware adapted with software.

The advantage of power management according to the described model is the possibility of storing produced energy in the transmission Grid, intended for specific types of receivers and transmitters of energy. The method is applicable for both: traditional electricity, renewable or alternative energy sources, thermal, cooling, water, geothermic, granular materials, air, gases under pressure, or energy obtained from the combustion of biomass or bio-components.

According to the given model all costs, investment and maintenance related to energy storage are covered by the grid owner. The client pays only some Grid Storage Fees (GSF) in the form of payment or in the form of transferring to the Grid some amount of energy in addition to the stored energy.

For storage with a financial settlement we get:

$$
Q m_{n}=Q w_{n}=Q o_{n}
$$

where: $Q m_{n}-$ Energy stored in the settlement period

$Q w_{n}$ - Energy transferred to the Grid in the settlement period

$Q o_{n}$ - Energy drawn from the Grid in the settlement period 
For storage where the settlement is regulated "extra", the energy delivered to the grid

$$
Q m_{n}=Q w_{n}-Q n_{n-1}=Q o_{n}
$$

where $Q n_{n-1}-$ Energy charged for the storage in the settlement period

For storing and buying energy

$$
Q m_{n}=Q w_{n}-Q n_{n-1}=Q o_{n}-Q k_{n}
$$

where $Q k_{n}-$ Energy bought in the accounting period

For storage and selling energy

$$
Q m_{n}=Q w_{n}-Q n_{n-1}-Q s_{n}=Q o_{n}
$$

$Q s_{n}-$ Energy sold in the accounting period

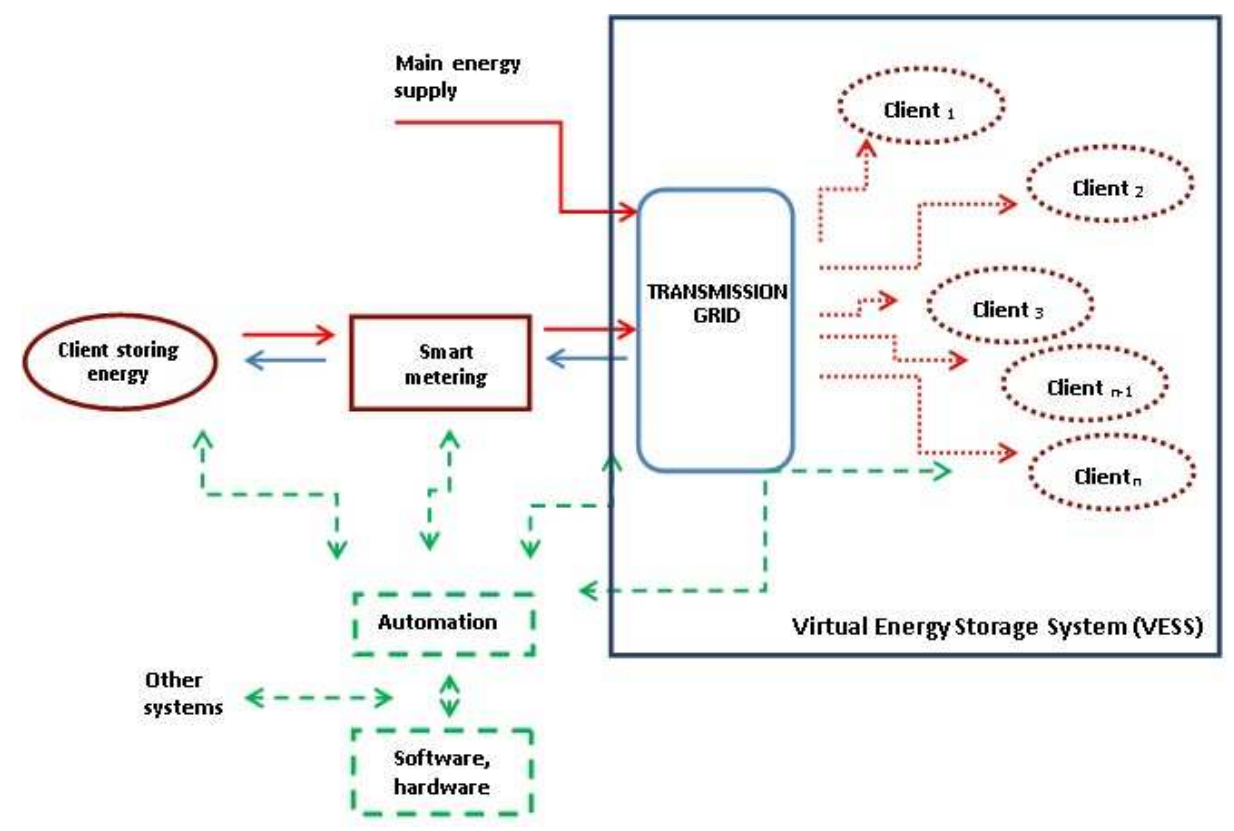

Figure 3. Virtual Energy Storage System (VESS)

The size and type of Grid Storage Fee (GSF) is set in each case among the grid owner / administrator and energy supplier. The additional advantage of the described energy management is that the charge is proportional to the amount of energy units stored in the transmission grid. Furthermore, it is not dependent on other fixed and variable charges arising from operation and the use of energy connections. 
The described method is also applicable in the case when the owner or Grid administrator charges the client depending on the connection capacity and in the situation when other fixed charges are introduced.

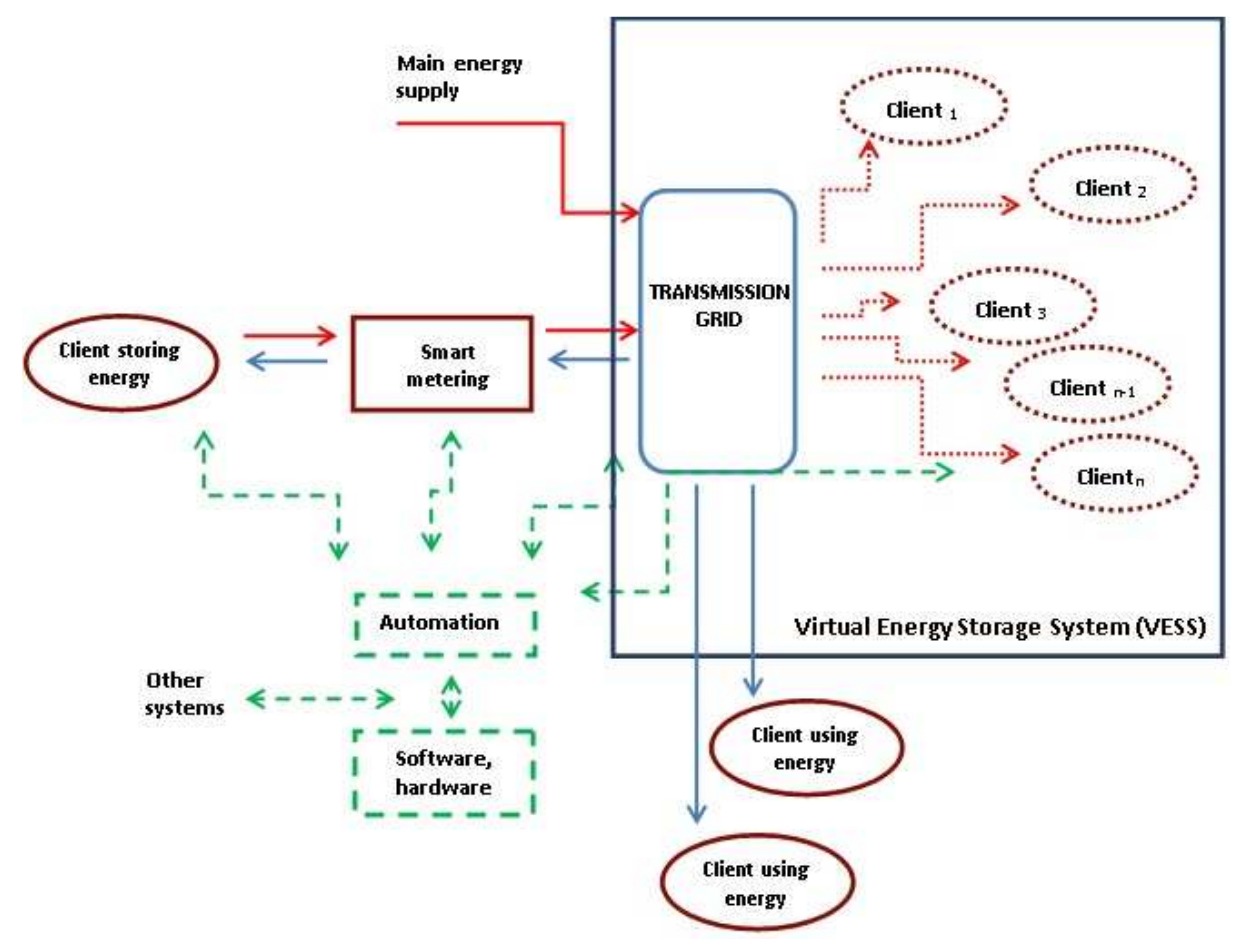

Figure 4. Virtual Energy Storage System (VESS) with several locations from the storing client

Figure 3 represents the model of a working VESS, when the client transfers the energy to the grid. The amount of transferred energy is measured by a smart meter, managed by an intelligent computer system. The storage system includes the grid and all its clients buying energy. The energy is used by other clients immediately, which minimizes self-discharge losses of theoretical batteries, which always occurs in physical storage methods. The VESS is constantly "charged" by the main energy supply source, the traditional generators in most cases, which must balance energy levels to a specific level. Then energy supply from the storing client will reduce the expenditure of energy to maintain the energy level in the grid. In other words, the energy is stored as unused fuel in the main power source. In such a situation, storing of energy occurs without losses, and only its recovery will entail a loss for transmission of the energy from the main generator to the client.

The expansion and development of this model is essential so if the storing client wants to get back the energy in a different location, for example in another building belonging to the same company, Fig. 4. It may be done via the transmission grid. The energy is produced on the one side and used on the other Client using energy. In such a case a contract with the owner of the grid can be both beneficial and convenient and based on both storing and instant use of the energy. 


\section{SMART GRID APPROACHING}

Smart grids are the result of a dynamic coevolution process, that enhance the integration of new technical advances in energy production plus information, communication techno$\log y^{3}$. The idea of smart and micro grids ${ }^{4}$ energy management to pair the cheapest energy and specific activity so that the production of daily energy utilization is as constant as possible. This is important not only for the best production efficiency but also for the safety of the power supply.

Smart Grid is an electro-energetic grid which includes a variety of systems and controls leading to the efficient utilization of produced energy from both renewable and traditional sources. Power conditioning and control of the production and distribution of electricity are very important aspects of the smart Grid. The issue is especially important because of the differences in use distribution of energy in time and the price deviations during the day. It is a common condition in Europe that the most desired energy is the European peak and especially between 12.00 and $2.00 \mathrm{pm}$. This is why at that time the energy is the most expensive and everyone should do there upmost to reduce the energy consumption. The cheapest and "undesired" energy comes at night. That is because human activity is reduced but power stations cannot be stopped.

It is logical that we should move all possible energy consumption to the night, when the energy prices come down and reach often even prices close to zero.

The VESS gives us the possibility to store energy in the grid, but also to use it in the most appropriate time, taking into consideration our activity profile and possibilities of energy generators. We can produce energy in the night and use it during the day or vice versa. Of course we can suppose that the one who produces and stores energy in the grid during the night and utilizes it through the day will be less desirable, than the one who produces energy at the European peak and transfers it to the grid as the most valuable energy. This is why in the summer the solar energy producer will be especially desired and during the winter, wind energy will have additional advantages. That means that depending on the energy source the supplier or buyer can suggest different conditions of collaboration, plus they can be different depending upon the periods and seasons.

Because of the failing human factor it is the best to use computers and automatic control systems for managing VESS system as well as generally Smart Grids. Such intelligent systems are not susceptible to the human error and we can expect the most efficient management of the whole system.

Applied automation should control the system optimizing it in the direction of lowest costs and highest efficiency. There are several issues important to control the VESS system:

- Controlling the voltage of a system ${ }^{5}$.

- Switching off some equipment, if possible, for example air-conditioning.

- Using the energy at the time of the lowest prices.

${ }^{3}$ L.M. Camarinha-Matos, Collaborative smart grids - A survey on trends, "Renewable and Sustainable Energy Reviews" 2016; 65; 283-294.

4 Y. Yoldas, A. Onen, S.M. Muyeen, A.V. Vasilakos, I. Alan, Enhancing smart grid with microgrids: Challenges and opportunities, "Renewable and Sustainable Energy Reviews" 2017; 72; 205-214.

5 Application of Automated Controls for Voltage and Reactive Power Management - Initial Results; Smart Grid Investment Grant Program 2012; U.S. Department of Energy. Electricity Delivery \& Energy Reliability. 
- Handling bidirectional energy flow, allowing for distributed energy

- Giving information from the grid to the customer about the overloading or other important notifications.

- Levelling peak consumption.

- Additional energy storing direct or in a converted form (heat pumps, tanks, refrigerators, flywheels etc. $)^{6}$.

- Smart metering.

- Smart grid security ${ }^{7}$.

\section{SUMMARY AND CONCLUSIONS}

Although the described model is already in use, the presentation should help to explore possibilities of using it for more efficient the management of energy. It is important to minimize losses and costs of production and transmission of energy. The precise measurement and management of energy should aim to introduce continuous stepless adjustment of the energy production amount from the main generating source.

If the client produces and introduces energy to the grid, he can use it in a different place. It does not refer only to buildings but also mobile devices like cars, bicycles, motorcycles, scooters or electronic devices. In this case, the owner of a hybrid vehicle can charge it anywhere and the energy used is deducted from his account.

All additional mobile devices create in the whole system additional mobile energy storage. Energy can be transmitted to devices directly with the use of cables or through induction. Any customer producing energy can use it anywhere. The amount of energy can be stored in a virtual bank and the client can use it in any place and with the use of any electrical device. Energy withdrawal can be done with the use of a card, or a mobile phone which saves all changes to the amount of stored energy.

In the macro level covering the entire globe the situation is even simpler. Because of changing time zones on every meridian in the world the energy rush hour occurs in different times. In such a situation there is no night for instance, where the use of energy drops dramatically, when some countries do not know what to do with unused energy. There is always a place where the PV installation works with its maximum power point. In such a situation we can talk about the sustainable global energy economy.

If we have a building with the annual use of energy about $3500 \mathrm{kWh}$, and we install the $7 \mathrm{kWp}$ PV system with the production AC of $7350 \mathrm{kWh}$ we get such results of energy flow:

\footnotetext{
${ }^{6}$ P. Crespo Del Granado, Z. Pang, S.W. Wallace, Synergy of smart grids and hybrid distributed generation on the value of energy storage, Applied Energy 2016; 170; 476-488; A.D. Carvalho, P. Moura, G.C. Vaz, A.T. de Almeida, Ground source heat pumps as high efficient solutions for building space conditioning and for integration in smart grids; "Energy Conversion and Management" 2015; 103; 991-1007; R.T. Doucette, M.C. McCulloch, A comparison of high-speed flywheels, batteries, and ultracapacitors on the bases of cost and fuel economy as the energy storage system in a fuel cell based hybrid electric vehicle, "Journal of Power Sources" 1996; 3; 1163-1170.

7 T. Flick, J. Morehouse, Securing the Smart Grid, Next Generation Power Grid Security, ISBN: 978-1-59749-570-7; F. Skopik, Smart Grid Security, Innovative Solutions for a Modernized Grid, ISBN: 978-0-12-802122-4.
} 
Energy (AC) production from PV installation

Energy Self-consumption

Energy transferred to the external Grid

Energy taken from the external Grid
$7350,4 \mathrm{kWh} /$ year

$1575,1 \mathrm{kWh} /$ year

$5775,3 \mathrm{kWh} /$ year

$1924,9 \mathrm{kWh}$

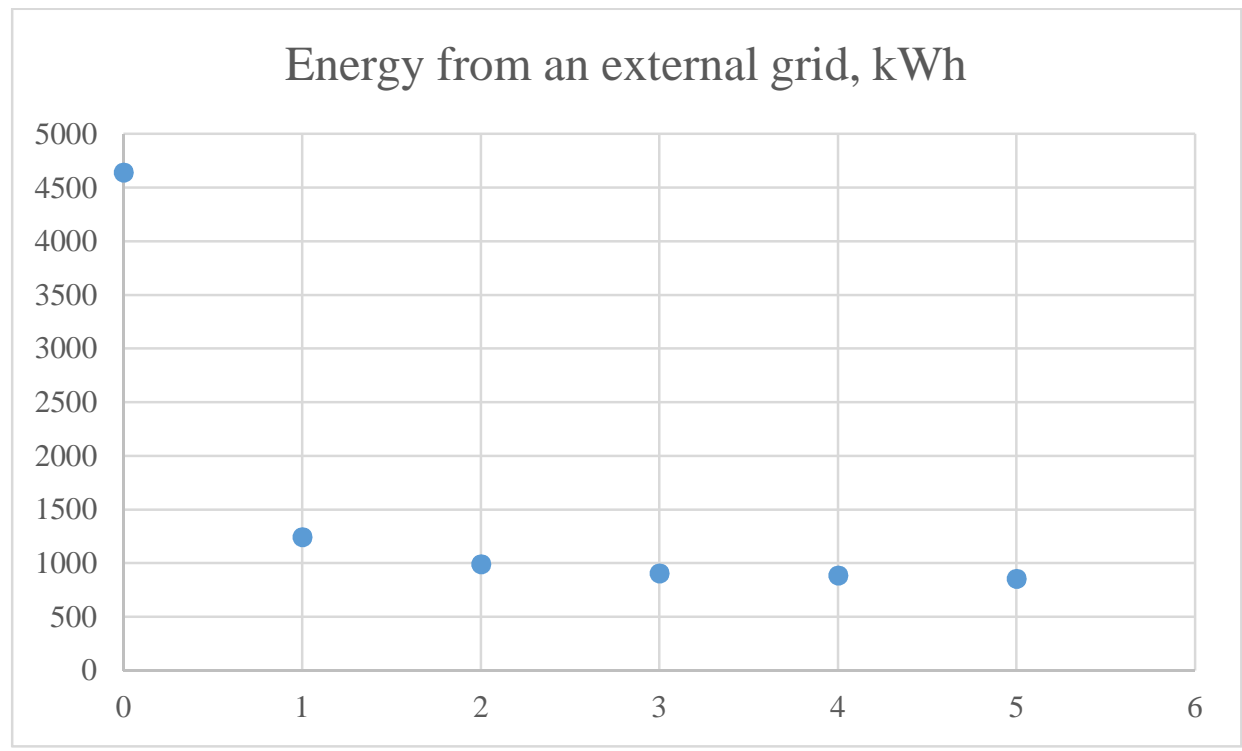

Figure 5. Energy received from the Grid by use of different amount of batteries Tesla $24 \mathrm{kWh}$ ( 0 to 5 batteries).

As we can see, even if we produce more than twice the amount of the energy we need, we have to use the grid as a buffer where we "store" energy while the production is higher than the use. That energy we can use at the time when production is lower than the utilization. We could use batteries to store energy, but the theory to build an energy sufficient system does not work so good in practice. As we can see on Figure 5, as the utilization of 1 battery drives the system quite fast in the direction of self-efficiency, but the use of each next one is less efficient than the previous one and the amount of energy from the grid heads asymptotically to some value but seems never to reach zero-point. This is why it is very difficult to build the sufficient system without additional restrictions in the ways of energy usage.

In the other situation when we deal with an auxiliary energy generator, we are able to produce the rest of the energy we need to cover all our requirements. But the energy can be bought or recovered from the grid after storing. This situation is more efficient for the customer because all energy produced is being used. And nothing is lost (unused).

It drives us to the conclusion that the best situation occurs when we deal with energy storage in the Grid, in which different utilization of energy by consumers meets perfectly the different production of energy in distributed energy systems. 
It is possible to store energy in the grid. It contributes to reducing the storage price of one GWh of energy as it uses mostly the existing infrastructure. This results in reduction of investment in professional storing systems.

Energy storing in the grid reduces power fluctuations by reducing the temporary peak load of industrial generators.

Decreasing of load fluctuation of energy generators lowers directly anthropogenic influence of energy on environment. VESS decreases also energy losses and what follows also the quantity of energy. That has significant influence on environmental protection.

\section{REFERENCES}

[1] Abdi H., Beigvand S.D, La Scala M., A review of optimal power flow studies applied to smart grids and microgrids, "Renewable and Sustainable Energy Reviews" 2017; 71; $742-766$.

[2] Ali S.M., Jawad M., Khan B., Mehmood C.A., Zeb N., Tanoli A., Farid U., Glower J., Khan S.U., Wide area smart grid architectural model and control: A survey, "Renewable and Sustainable Reviews" 2016; 64; 311-328.

[3] Application of Automated Controls for Voltage and Reactive Power Management - Initial Results; Smart Grid Investment Grant Program 2012; U.S. Department of Energy. Electricity Delivery \& Energy Reliability.

[4] Camarinha-Matos L.M., Collaborative smart grids - A survey on trends, "Renewable and Sustainable Energy Reviews" 2016; 65; 283-294.

[5] Carvalho A.D., Moura P., Vaz G.C., de Almeida A.T., Ground source heat pumps as high efficient solutions for building space conditioning and for integration in smart grids, "Energy Conversion and Management" 2015; 103; 991-1007.

[6] Crespo Del Granado P., Pang Z., Wallace S.W., Synergy of smart grids and hybrid distributed generation on the value of energy storage, "Applied Energy" 2016; 170; 476-488.

[7] Doucette R.T., McCulloch M.C., A comparison of high-speed flywheels, batteries, and ultracapacitors on the bases of cost and fuel economy as the energy storage system in a fuel cell based hybrid electric vehicle, "Journal of Power Sources" 1996; 3; 1163-1170.

[8] Flick T., Morehouse J., Securing the Smart Grid, Next Generation Power Grid Security, ISBN: 978-1-59749-570-7.

[9] Hossain M.S., Madlool N.A., Rahim N.A., Selvaraj J., Pandey A.K., Khan A.F., Role of smart grid in renewable energy: An overview, "Renewable and Sustainable Energy Reviews" 2016; 60; 1168-1184.

[10] Kabalci Y., A survey on smart metering and smart grid communication, "Renewable and Sustainable Energy Reviews" 2016; 57; 312-318.

[11] Polysun Simulation Software User Manual; Vela Solaris AG, Switzerland; 2016

[12] Skopik F., Smart Grid Security, Innovative Solutions for a Modernized Grid, ISBN: 978-0-12-802122-4.

[13] Yoldas Y., Onen A. Muyeen S.M., Vasilakos A.V., Alan I., Enhancing smart grid with microgrids: Challenges and opportunities, "Renewable and Sustainable Energy Reviews" 2017; 72; 205-214. 


\section{WIRTUALNY SYSTEM PRZECHOWYWANIA ENERGII (VESS) ZA POMOCA INTELIGENTNEGO ZARZĄDZANIA SIECIĄ (SMART GRID)}

Artykuł pokazuje wirtualny sposób magazynowania energii w sieci przesyłowej traktujący samą sieć oraz wszystkich podłączonych odbiorców energii jako jeden system magazynowania energii. Opisywany system zasilany jest energią wytwarzaną w sposób tradycyjny oraz pochodzącą z alternatywnych źródeł energii. Energia jest zużywana przez dużą grupę rozproszonych klientów. Teoria opiera się na zmianach stref czasowych, które determinują różne zużycie energii w różnych czasach i lokalizacjach. W skali mikro system nie jest komplementarny i wymaga wkładu mocy szczytowej, a także dodatkowego magazynowania. Jednak w poniższym przypadku nie jest konieczna konstrukcja dużych systemów magazynowania energii, lecz połączenie jedynie mniejszych jednostek magazynowych, jeśli występuje taka konieczność. Jest to zjawisko polegające na wykorzystywaniu systemu energetycznego jako pewnego rodzaju bufora. $\mathrm{W}$ artykule przedstawiono kilka metod obliczania przepływu energii. Opisano dwie możliwości. Pierwsza występuje wtedy, gdy klient produkuje i magazynuje energię w sieci, aby użyć ją później w tym samym miejscu. Druga polega na wytworzeniu energii $w$ jednym miejscu i wykorzystaniu jej $w$ innym. W tym przypadku sieć nie służy tylko do magazynowania energii, ale także do przeniesienia jej do innych odbiorników lub odbiorców.

Słowa kluczowe: magazynowanie energii; sieć elektroenergetyczna; wirtualny magazyn; inteligentne sieci; VESS.

DOI: $10.7862 /$ rz.2017.hss.49

Przestano do redakcji: kwiecień $2017 \mathrm{r}$.

Przyjęto do druku: wrzesień 2017 r. 